\title{
Mergulho na estação do Inferno
}

\author{
Eltânia André ${ }^{1}$
}

"A realidade é essa coisa sórdida e bruta. E seu presente é todo feito de passados". (Samuel Rawet)

Após uma reconhecida trajetória pela literatura infanto-juvenil, tendo publicado dezoito livros no gênero, Lucília Garcez estreia na prosa adulta com o romance Outono, obra ficcional que faz uma imersão nos anos de chumbo que marcaram o longo período da ditadura militar brasileira.

Narrada quase em sua totalidade na primeira pessoa, impera a voz da protagonista Ângela, uma brasileira que testemunhou e viveu a sua juventude nos anos que se sucederam ao golpe militar que depôs o presidente constitucional João Goulart e levou o País a uma era de obscurantismo e terror. Percorrendo através de sua dor os bastidores do poder e a vilania do sistema, Ângela mergulha no emaranhado desse tempo e nos conta sobre Danilo, vítima dos algozes do regime. Ele, jovem estudante da Capital da República, "era contra a luta armada, contra a violência, mas compreendia a opção de seus colegas e era solidário" (GARCEZ, 2018, p. 67), não sucumbiu ao medo e manteve seus ideais libertários, foi preso ao ser flagrado em via pública colando cartazes convocando para uma marcha, sofreu a tortura e foi assassinado pelos agentes da repressão.

Diante das circunstâncias que se impunham naqueles anos trágicos, a protagonista teve que se render à opressão, seguir em frente em meio às al- ternativas que restaram para criar sozinha a filha recém-nascida (que não teve chance de conhecer o pai), e carregando ao longo dessa ausência e no curso desse pesadelo, o passado como um fantasma que, além de assombrar, avilta. Já havia enfrentado o silêncio, a falta de notícias, o vazio, tudo se misturando como se fora um câncer social que se multiplicaria em metástases. O corpo insepulto de Danilo é o objeto de amor perdido no tempo, no espaço, na memória; é a impossibilidade de concluir o luto.

No decorrer da história nota-se a assunção, de forma pontual e discreta, de um narrador onisciente em terceira pessoa, que sussurra para o leitor o que se passa com Francisco, personagem que despertará em Ângela a mulher e a sensualidade recusada, ignorada ou reprimida durante anos. E em um certo momento, o leitor é confrontado também com as vozes dos carrascos de Danilo quando explicitado um momento sádico da tortura. Vale destacar que não coube à autora inventar o destino atroz do Danilo (comum a tantos naquela prolongada estação de horror), que o aniquilamento e a ocultação de cadáver não são mero fruto da imaginação ou da ficção, impõe-se aqui a força da realidade a conduzir a pena da autora, pois ela está mais viva e desafiante do que nunca. Eis que em Outono Lucília dá voz e vez ao mundo real, que abre as portas do assombro e da barbárie, embora para muitos possa parecer, equivocadamente, algo distante e vencido. A incursão da autora por esse tempo de vicissitudes pessoais e coletivas remete-nos analogamente a um episódio

1 Pós-graduada em Psicopatologia e Saúde Mental. Graduada em Administração de Empresas e Psicologia. Natural de Cataguases-MG. Escritora, autora dos livros: Manhãs adiadas, contos, Dobra Editorial, SP, 2012; Para fugir dos vivos, romance, editora Patuá, SP, 2015; Diolindas, romance, editora Penalux, SP, 2016, escrito em parceria com Ronaldo Cagiano; Duelos, contos, editora Patuá, SP, 2018. São Pedro do Estoril, Portugal. ORCID: http://orcid.org/oooo-0002-1172-8588. E-mail: eltaniaandre@hotmail.com 
envolvendo Pablo Picasso: quando o pintor espanhol foi acossado por um oficial do regime que, horrorizado com seu quadro "Guernica", perguntou-lhe se ele era o autor daquela obra, tendo Picasso respondido que não, que tinham sido eles que o fizeram. Lucília representa metaforicamente em Outono esse mesmo sentimento, idêntica constatação, o do horror e da catástrofe que se abateram sobre o País, eles criaram seus monstros e coube à sua habilidosa arte ficcional apenas dar-lhes cara, nome e condenação.

A autora encampa nesse romance a ideia de desmoronamento das utopias em um momento em que a História dá suas voltas e lança-nos novamente ao retrocesso, culminando em novos tempos de declínio democrático e apelo saudosista à era dos coturnos e das baixas. Na esteira desse pressentimento, Outono, em clave de diálogo, flerta com a recente obra de Milton Hatoum, A noite da espera, primeiro volume da trilogia O lugar mais sombrio, pois deambula pelos mesmos cenários políticos e sociais dos nossos anos mais duros, tempos em que a vivência do exílio (seja ele interno ou fora do País), impunha o deslocamento como um imperativo para a sobrevivência.

Danilo representa outros corpos desaparecidos e o silêncio como resposta tipicamente brasileira aos nossos dilemas e perplexidades, essa mudez que não consola e não traz clareza ao passado. Assim a Ângela de Lucília antecipa a Elizabete de agora, outra viúva de desaparecido, outra brasileira que nunca enterrou o seu companheiro: Amarildo saiu para comprar limão e alho, sabe-se que foi detido pela UPP (Unidade de Polícia Pacificadora) e nunca mais voltou para casa, seu corpo nunca foi encontrado, como tantos são os corpos que a história não deu sepultura. A pergunta do povo e de Elizabete - Onde está Amarildo? - nunca foi respondida. É a mesma indagação da protagonista que nunca soube do corpo de Danilo. Igualmente simbólicos (e criminosos) são os desastres ambientais de Mariana e Brumadinho, fruto da incúria e do descaso do poder econômico tanto com a vida quanto com a natureza, pois a voracidade capitalista pode enterrar uma nação, como as mortes e tantos corpos não encontrados soterrados pela tragédia causada pela Vale do Rio
Doce em Brumadinho, a mesma lama da ditadura que comprometeu o futuro de Ângela e sua família, agora torna inamovível o horizonte dos desaparecidos de Minas Gerais, metáfora da impunidade, seja nos acordos comerciais ou na truculência da história política.

Enquanto a protagonista de Outono relembra os fatos históricos e confidencia a sua singularidade, aponta para o leitor que a sua energia vital é abastecida e suavizada pelos livros e pela convivência "no meio das plantas, vasos, mudas, terra e adubo..." (GARCEZ, 2018, p. 128), pois trabalha como paisagista; faz referência ao longo da obra a vários livros, às leituras e autores que preenchem o vazio deixado pela ausência do marido, entre os quais $O$ amante de Lady Chatterley, de Lawrence; Crônica de uma morte anunciada, de Gabriel García Márquez; Aleph e Antologia pessoal, de Borges; O túnel, de Ernesto Sábato; Lavoura arcaica, de Raduan Nassar; referências que a socorreram ao longo de sua vida. Ela nos diz que "para onde fosse sempre levava um livro. Era um recurso infalível contra a monotonia e o vazio. Por causa da leitura me afastava de outras atividades e abrira mão de outras experiências" (GARCEZ, 2018, p. 123). E é através desse imenso mundo bibliográfico que conhece Francisco, cerca de dez anos mais novo, dono de uma pequena livraria nas proximidades de sua casa. É uma presença que provoca em Ângela sensações adormecidas ou negligenciadas, como a sutileza de um toque que revigora, como se pode notar em uma passagem do livro quando ele a toca carinhosamente nos ombros: "Percebi o gesto e usufruí de uma sensação agradável de intimidade, como se uma onda protetora e acolhedora me tivesse envolvido momentaneamente" (GARCEZ, 2018, p. 125); embora, ela ainda parece recusar, pois termina dizendo: "Uma aceitação, uma aprovação por ser quem era, uma leitora" (GARCEZ, 2018, p. 125). Nesse sentido, a leitura e seus prazeres cumprem um papel nessa lacuna intransponível, ela os absorvia como se fossem Eros.

A personagem encarna traços sutis de uma mulher que atuava timidamente sobre o seu desejo frente à lógica patriarcal, por muitas vezes se posicionou 
como expectadora dos acontecimentos; ela mesma supõe ao longo da história como seria a reação de Danilo diante "disso-daquilo" e se priva dos seus desejos e escolhas. É o que emerge de trechos como estes: "As mulheres estavam mais atiradas, mais oferecidas. Estavam decididas a usufruir intensamente da liberdade conquistada" (GARCEZ, 2018, p. 34); "Ele era generoso e compreensivo. Sempre admirei sua paciência e tolerância, principalmente enquanto eu aprendia a cozinhar" (GARCEZ, 2018, p. 41); "Os reflexos da beleza que devia ter tido na juventude (GARCEZ, 2018, p. 62); "Eu o admirava de forma incondicional. Nunca fui tão envolvida em política com ele e prezava minha segurança. [...] Eu compreendia e respeitava suas opções solidariamente" (GARCEZ, 2018, p. 66); "Não precisaria me preocupar em manter as roupas dele em ordem, como ele gostava: uma camisa em cada cabide, as calças na mesma posição, as gavetas impecáveis..." (GARCEZ, 2018, p. 87). É importante registrar a maneira delicada com que a autora traz à tona esses persistentes traços que podem ser herdados de uma cultura social e familiar. Outro momento do livro como exemplificação: o choque que teve a filha de Ângela ao se deparar com a mulher para além da mãe e se negar, em um primeiro momento, a estar ao seu lado.

A intertextualidade é uma das características marcantes que integram o ritmo e a trama do livro, e somos levados a participar de seu universo sensorial, em uma corrente musical com clássicos da resistência como: Roda Viva, de Chico Buarque; Para não dizer que não falei de flores, de Geraldo Vandré; Grândola Vila Morena, de Zeca Afonso, a voz de Milton Nascimento nas mobilizações das "Diretas Já”, referências paradigmáticas de uma época. Mas, é Rosa Passos que ganha espaço e carrega Ângela para se revigorar com o sexo e a possibilidade de amar novamente - e desamar e amar; diria ainda que Rosa poderia muito bem orquestrar toda a trama. O cinema é outra linguagem que entra na composição desse imaginário, pois também contribuiu para o enfrentamento dos tempos difíceis. A autora visita obras icônicas da Sétima Arte: O que é isso, companheiro?, baseado no livro homônimo de Fernando Gabeira e dirigido por Bruno Barreto; O dia que durou 21 anos, de Camilo Tavares; Que bom te ver viva, de Lúcia Murat; Pra frente, Brasil, de Roberto Farias; além de Cidadão Boilesen, de Chaim Litewski - documentário sobre um dos financiadores da máquina ditatorial.

Outono percorre os acontecimentos desde os primórdios do golpe, relembrando a hipnose do futebol, enquanto o regime endurecia nos porões até culminar com a promulgação do AI-5 e a consequente perda generalizada de direitos; os exílios, como os de Paulo Freire, Milton Santos, Darcy Ribeiro, Niemeyer, Ferreira Gullar e tantos outros; o assassinato de Vladimir Herzog; a Sexta-feira Sangrenta; a Passeata dos Cem mil; as greves no ABC na expressão da luta trabalhista como resultado de um novo sindicalismo; chegando à agonia do regime com a campanha pelas Diretas Já até à criação da Comissão Nacional da Verdade, instaurada para investigar as violações de direitos cometidas entre 18 de setembro de 1946 e 5 de outubro de 1988.

Outono, de Lucília Garcez, é um espelho de nossa (mal contada) história de um Brasil e de seres à deriva, sempre atormentados pelo passado, que o pêndulo dos tempos insiste em reprisar. Uma obra, sem dúvida, de intensidade crítica e reflexiva que, com uma linguagem cristalina, toca em feridas não cicatrizadas.

\section{Referências}

GARCEZ, Lucília. Outono. Brasília: Outubro Edições, 2018. $184 \mathrm{p}$.

Recebido em: 26/3/2019

Aprovado em: 24/4/2019

\section{Eltânia Maria de Sousa André}

(sem vínculo a instituição)

São Pedro do Estoril, Portugal

Orcid: http://orcid.org/oooo-0002-1172-8588

E-mail: eltaniaandre@hotmail.com

Endereço de correspondência: Rua 9 de abril, 219A, 1Dt. São Pedro do Estoril, Portugal - 2765-543 